$\xi=$ 礉

\title{
Petrophysical evaluation and lithology delineation using cross-plots analysis from some onshore wells in the Nigerian-delta, west Africa
}

\author{
Michael Ohakwere-Eze ${ }^{1} *$, Magnus Igboekwe ${ }^{1}$, Godwill Chukwu ${ }^{1}$ \\ ${ }^{I}$ Department of Physics, College of Physical and Applied Sciences, Michael Okpara University of Agriculture, Umudike. Abia State, Nigeria. \\ *Corresponding author E-mail: michael.ohakwereze@gmail.com
}

\begin{abstract}
Reservoir rock attributes such as porosity, permeability, pore-size geometry and net-to-gross ratio can grossly be affected by inaccurate delineation of the sand intervals. It is therefore pertinent that well log cross-plot is utilized to accurately delineate the sand body and correctly evaluate the petrophysical properties of the mapped sandstone intervals. Three wells (A, B and C) were studied from which analysis of various cross-plots were done. The cross-plots of the density and gamma ray, Acoustic impedance and VpVs ratio with various colour indicators such vertical depth, porosity, resistivity, water saturation etc. were generated using the Hampson Russel software. The hydrocarbon interval in the area occurs between 5870ft to $8900 \mathrm{ft}$ for well-A, 5500ft to 5910ft for well-B and 5700ft to $7230 \mathrm{ft}$ for well-C as interpreted from the well logs with an average porosity range from 26 to $39 \%$. Cross-plot analysis was carried out to validate the sensitivity of the rock attributes to reservoir saturation condition. The cross-plot results clusters shows two major lithologies of sandstone and shale with occasional intercalation of sand and shale units. For the three wells considered, ten reservoirs were observed. Fluid detection analysis shows that reservoirs A1-A2 (well-A), B1-B2 (well-B), C3-C4 (well-C) were found to contain oil, while reservoir A3-A4 (wellA) and C1-C2 (well-C) contains gas. This study has shown that the cross-plots approach can be used to accurately delineate reservoirs for further formation evaluation. It therefore means that an outright estimation of petrophysical properties on wrongly delineated reservoirs can significantly affect the porosity, permeability, pore-size geometry and net-to-gross ratio of the reservoir units.
\end{abstract}

Keywords: Cross-Plot; Porosity; Reservoir; Sand; Well.

\section{Introduction}

Exploration for new reserves and recovery from existing accumulations have become increasingly challenging due to inadequate description and delineation of reservoir architecture using well logs, seismic and geological information (Ekine and Ibe 2013; Adewoye et al. 2015). Detailed petrophysical evaluation is usually required for optimized development and production, especially in the highly heterogeneous environments like the paralic successions of the Agbada formation of the Niger Delta area of Nigeria. In order to resolve this challenge, the use of well log cross-plots and petrophysical studies to predict the reservoir properties and lithofacies were employed in this study.

Cross-plotting or statistical techniques enable evaluation of lithology and pore fluid variations on both regional and detailed reservoir scales (Hunze and Wonik 2007; Lamont et al. 2008). Gray and Andersen (2000) as well as Anderson and Gray (2001) had demonstrated that many different lithologies like coal, shale, sandstone, gas saturated sands and carbonates can be identified by cross-plots of well logs (e.g. resistivity vs gamma ray, density versus gamma ray). The objective of this study is to analyze well logs in order to delineate the lithofacies and predict the reservoir qualities of the sand units using the clusters of log cross-plots (Chatterjee and Paul 2012) and petrophysical evaluations. Cross plots are visual representations of the relationship between two or more variables, and they are used to visually identify or detect anomalies which could be interpreted as the presence of hydrocar- bon or other fluids and lithologies. Cross plot analysis are carried out to determine the rock properties/attributes that better discriminate the reservoir (Omudu et al., 2007).

\section{Research aim and objectives}

The research aim is to use rock Physics analysis of well log data and attributes from AVO inversion of the anisotropic 3D Seismic data to delineate the lithology and fluid property

TECHNICAL OBJECTIVES: The objectives of this research are highlighted as follows;

1) To attempt a detailed reservoir correlation of the sand bodies.

2) Analyze the uncertainties and choice of a suitable set of seismic attributes.

3) Perform well and seismic data conditioning to help to improve signal-to-noise ratio and enhanced accuracy and stability of results.

4) Perform cross plot analysis and maps of the key attributes.

\section{Materials and methods}

Wire line well log data in LAS format were obtained for three wells from an onshore Niger Delta field. The well log data comprised sonic $\log$, density, resistivity log, caliper log, porosity $\log$ and gamma ray (GR) log (Table 1). 
The well log data were processed to obtain to a large extent consistent and accurate logs from well to well. We assumed that the well log data used had been corrected for wash out effects and other borehole irregularities. However, it was imperative to edit the logs further to enhance their fidelity for use in reservoir characterization. The Hampson Russel software package was used for the well $\log$ analysis. The logs were de-spiked using a median filter to ensure they contain only appropriate ranges of values.

Table 1: Studied Wells Showing Suite of Logs in Each Well

\begin{tabular}{|c|c|c|c|c|c|c|c|}
\hline $\begin{array}{l}\text { Wel } \\
\text { ls }\end{array}$ & $\begin{array}{l}\text { P- } \\
\text { wav } \\
\text { e } \\
\text { (ft/s } \\
\text { ) }\end{array}$ & $\begin{array}{l}\text { Den- } \\
\text { sity } \\
(\mathrm{g} / \mathrm{cc})\end{array}$ & $\begin{array}{l}\text { Gam- } \\
\text { ma- } \\
\text { ray } \\
\text { (API) }\end{array}$ & $\begin{array}{l}\text { Resis- } \\
\text { tivity } \\
\text { (Ohm- } \\
\text { m) }\end{array}$ & $\begin{array}{l}\text { Poros- } \\
\text { ity } \\
(\%)\end{array}$ & $\begin{array}{l}\text { Cali- } \\
\text { per } \\
(\mathrm{cm})\end{array}$ & $\begin{array}{l}\text { Check- } \\
\text { shot } \\
(\mathrm{ms})\end{array}$ \\
\hline A & $\sqrt{ }$ & $\sqrt{ }$ & $\sqrt{ }$ & $\sqrt{ }$ & $\mathrm{x}$ & $\mathrm{x}$ & $\mathrm{X}$ \\
\hline B & $\sqrt{ }$ & $\sqrt{ }$ & $\sqrt{ }$ & $\sqrt{ }$ & $\sqrt{ }$ & $\mathrm{x}$ & $X$ \\
\hline C & $\sqrt{ }$ & $\sqrt{ }$ & $\sqrt{ }$ & $\sqrt{ }$ & $\mathrm{x}$ & $\sqrt{ }$ & $\sqrt{ }$ \\
\hline
\end{tabular}

Median filters were also applied on vital logs such as P-wave velocity and density logs to reduce abundant small spikes on the data. The median filter operation replaces the sample value at the center of the operator with the median of the sample values contained within the operator, the longer the operator length the smoother the log. This process was largely experimental in order to isolate the best log operator length and we observed that with an operator length of 6 , the logs were largely well smoothened thus removing the high frequency noise. Small operator lengths would retain spikes in the data and adversely affect future cross plots and synthetic interpretation. On the other hand, if the operator lengths were too large, the cross plots might not be representative of the data and synthetics would not provide adequate details for seismic correlation. (Ohakwere-Eze M. C et al, 2014)

Shear wave log was empirically generated from the available logs according to Castagna's linear transform equation,

$\mathrm{V}_{\mathrm{s}}=\mathrm{C}_{1} * \mathrm{~V}_{\mathrm{p}}+\mathrm{C}_{2}$

Where,

$\mathrm{C} 1=0.86190$

$\mathrm{C} 2=-3845.14439$

Other logs (porosity and water saturation), were generated using different empirical relations. Porosity was calculated from density and resistivity according to the equation.

$\phi=\frac{0.9 \sqrt{\left[R_{v} / R_{t}\right.}\left(\rho_{w}-\rho_{k}\right)+\left(\rho_{m a}-\rho_{w s}\right)}{\left(\omega_{m a}-\rho_{k}\right)}$

Where

$\rho_{\mathrm{w}}$ is the density of formation water (Default Brine) $=1.09$ gram/cc

$\rho_{\mathrm{h}}$ is the density of hydrocarbons (Default Oil) $=0.75 \mathrm{gram} / \mathrm{cc}$ $\rho_{\mathrm{ma}}$ is the density of Matrix (Default Sandstone $)=2.65 \mathrm{gram} / \mathrm{cc}$ $\mathrm{Rw}$ is the resistivity of formation water $=0.04 \mathrm{ohm}$-meters

$\mathrm{R}_{\mathrm{t}}$ is true resistivity from the $\log$

$\rho_{\text {obs }}$ is observed density from the log

The Water Saturation, $\mathrm{Sw}$ which is the fraction of a pore volume that is filled with water was estimated using Archie's equation as expressed below,

$$
S_{w}=\sqrt{a \phi^{m} \frac{R_{w}}{R_{t}}}
$$

Where,

$\mathrm{a}$ is the cemetation factor $=0.62$

$\mathrm{m}$ is the cemetation exponent $=-2.15$

$\mathrm{Rw}$ is the resitivity of formation water $=0.04 \mathrm{ohm}$-metre

In this study, a suite of well logs from wells A, B and C (Table 1), obtained from a Niger Delta oil field was analyzed using the Hampson Russell software to generate log cross-plots that were interpreted. The cross-plots of the gamma ray with density (GRRHOB), P-impedance with $\mathrm{VpVs}$ ratio with their attribute cross session all against depth were generated using this software. These cross-plot clusters were used to accurately delineate the different lithofacies and mark out the reservoirs units for further petrophysical evaluation.

The main workflow carried out in this work include: well-log editing \& modelling and well log cross-plotting. After data importation, a log editing and conditioning were carried out. The log editing operations applied in this work include mainly checkshot correction and median filtering.

A check shot correlation was carried out (fig 1) which modifies the depth-time curve associated with a sonic log in order to improve the tie between a synthetic and real seismic data. This is necessary because the program extrapolates the first $\mathrm{Vp}$ value to the surface, which usually overestimates the near surface.

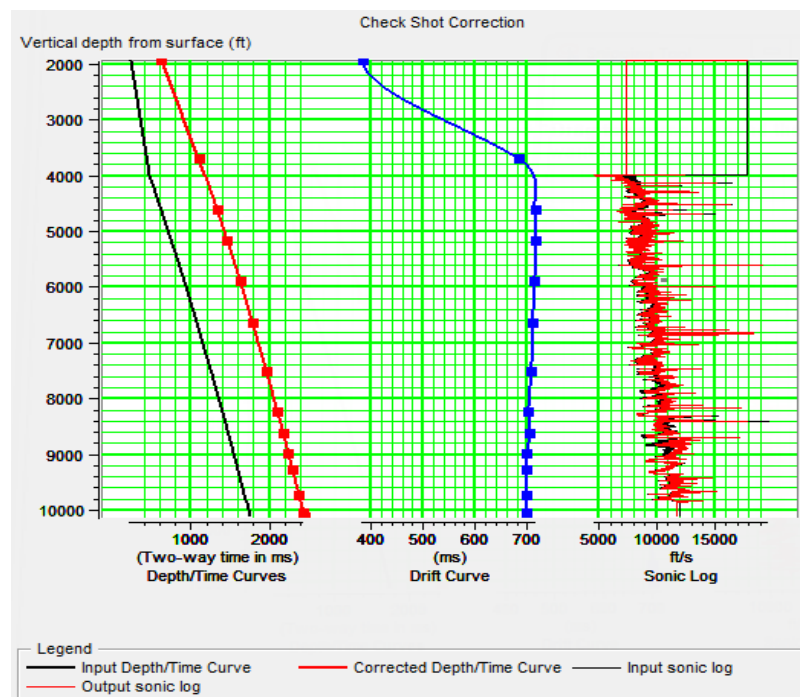

Fig. 1: Checkshot Correction Applied to Sonic Log Data. The Sonic Curves at the Far Right Show the Original Curve in Red and the Effect of the Correction, Shown in Black.

The goal of this rock physics analysis is to determine the feasibility of discriminating between reservoir facies and imaging architecture using seismic attributes. Several cross-plots were done, but the ones with the most significant discriminating power between litho-fluid facies was used for analysis.

Using rock physics algorithm, rock attributes which includes Elastic-impedance and $\mathrm{VpVs}$ ratio rock property volumes were extracted from the well data. The cross-plot analysis was carried out to determine fluid and lithology response of the rocks.

\section{Results and discussion}

\subsection{Well $\log$ analysis}

The well logs from the 3 wells, in LAS format, were loaded into the Hampson-Russell Geoview/Explorer module and later exported to e-log window from where it was analyzed (fig 4-6). Wells are situated in the eastern part of the field (fig 2). 


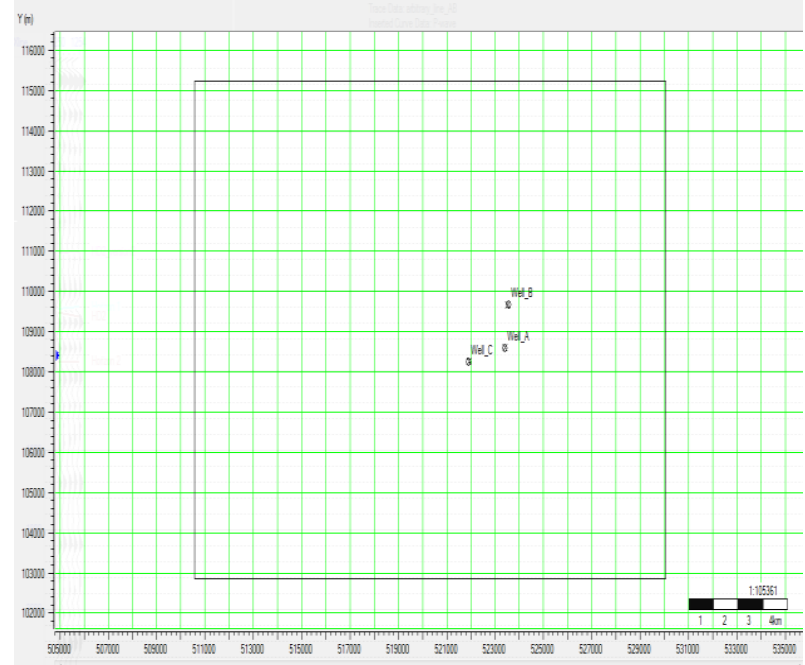

Fig. 2: The Base Map of the Study Area.

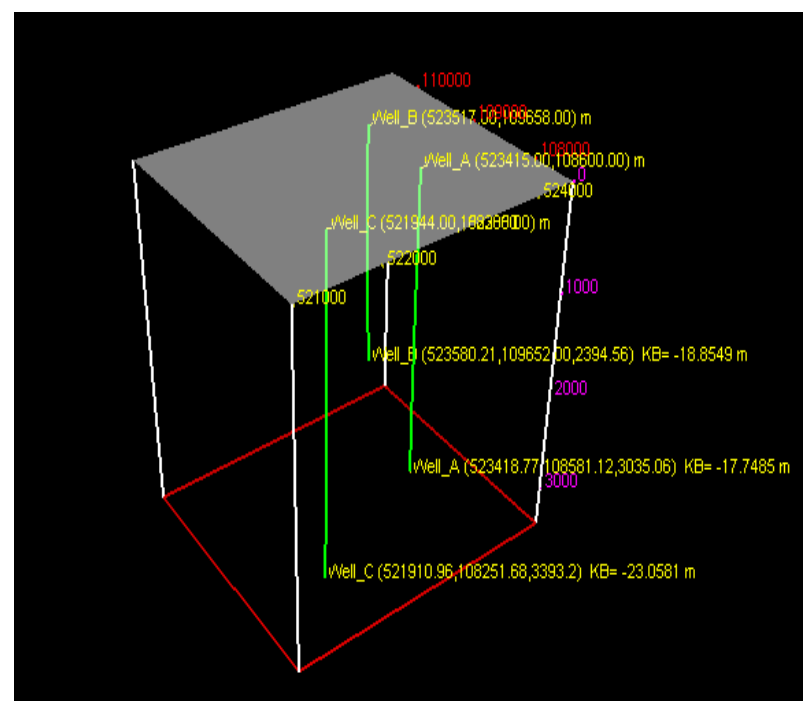

Fig. 3: 3D View of the Well in the Study Area.

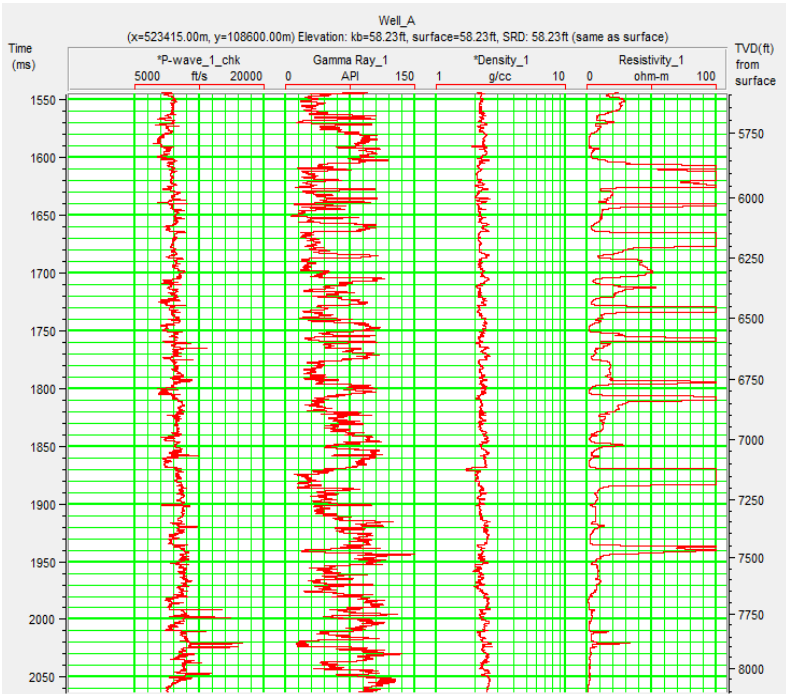

Fig. 4: Wireline Log Data for Well-A Showing Suite of Logs (RED COLOUR).

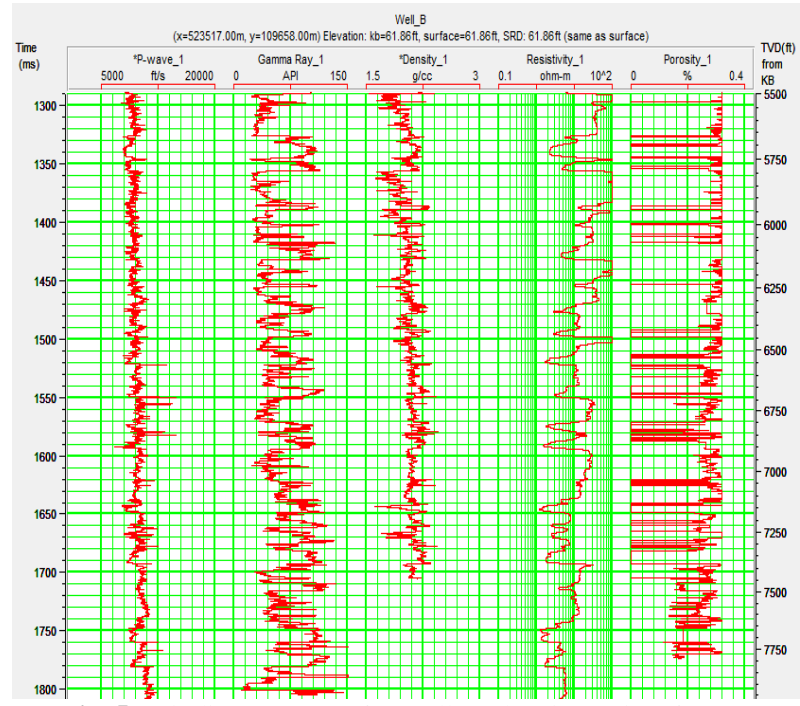

Fig. 5: Wireline Log Data for Well-B Showing Suite of Logs.

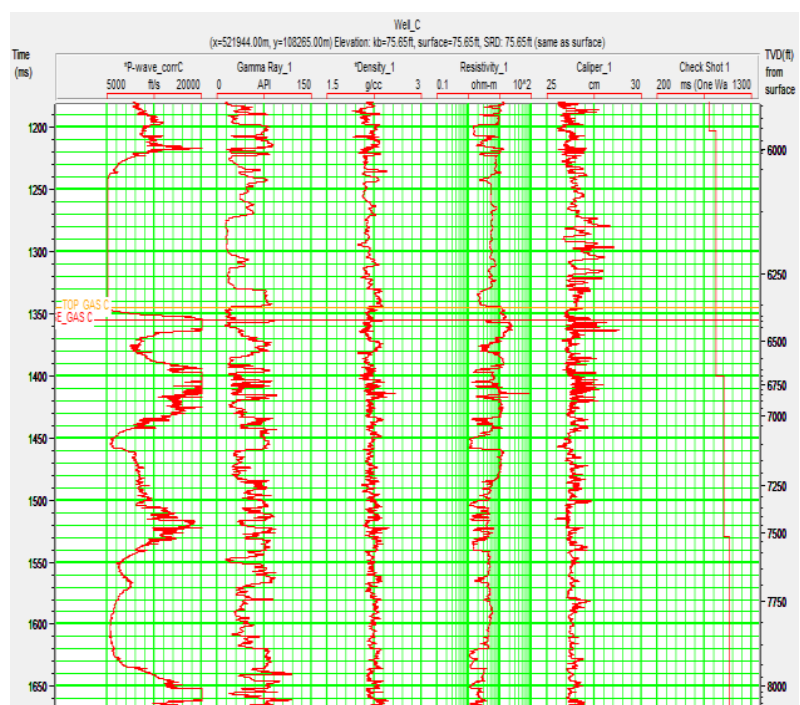

Fig. 6: Wireline Log Data for Well-C Showing Suite of Logs.

\subsection{Well-log modeling}

Using different empirical equations (Equation 1-3) various logs such as $\mathrm{S}$-wave, porosity, P-impedance, water saturation, $\mathrm{VpVs}$ ratio, Poisson etc. were generated (Fig 7).



Fig. 7: Wireline Log Signatures Obtained in the Area of Study From One of the Wells (Well C) Used in This Study Showing Some Transformed Logs. 


\subsection{Cross-plot of gamma-ray (GR) against density (RHOB)}

In this display (fig 8), low Gamma Ray values are more easily identified with the green fill color. Low gamma ray values are a good indicator of sands. We can improve the interpretation of this well by examining the other logs (fig 9).

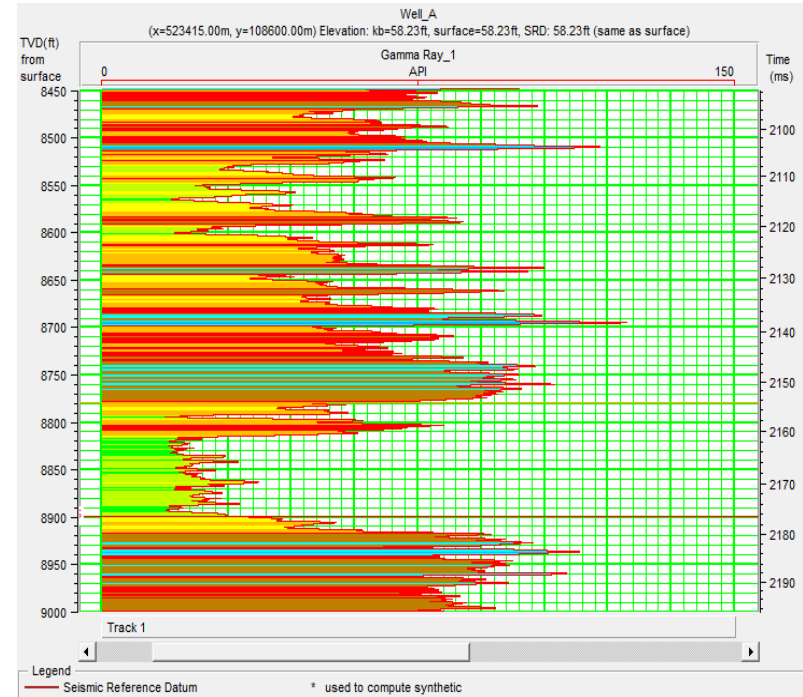

Fig. 8: Close-Up of Gamma Ray Log of Well-A.

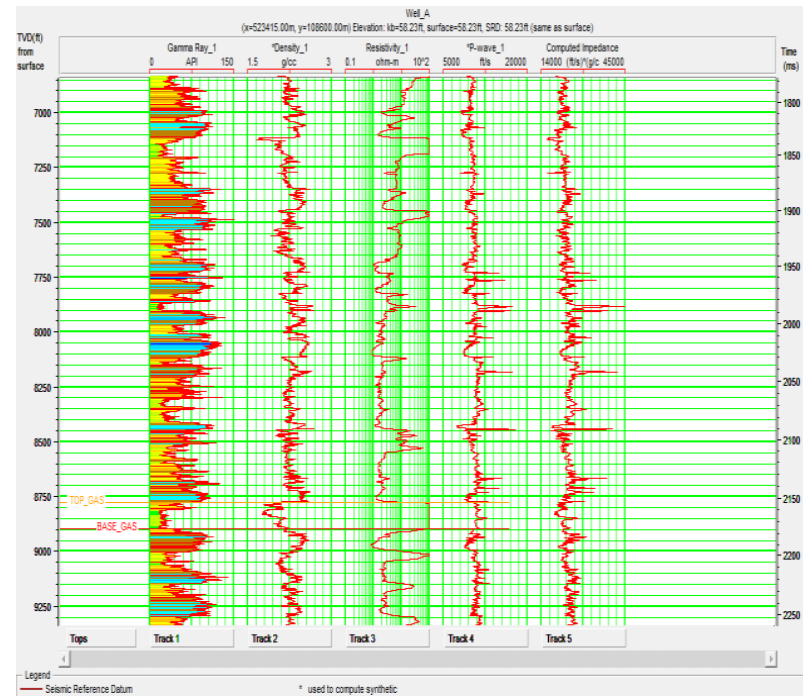

Fig. 9: Wireline Log Data for Well-A Showing Interpreted Mapped Sand Areas.

Cross-plots as a function of vertical depth

As seen in Well-A, the best reservoir is within deeper depth between 6934 to $8900 \mathrm{ft}$ (fig 10). However in Well-B, reservoir is at low depth between 5500 and 5910ft (fig 11). Whereas, best reservoir for Well-C is at lower depth between 5700 and $6400 \mathrm{ft}$ (fig 12).

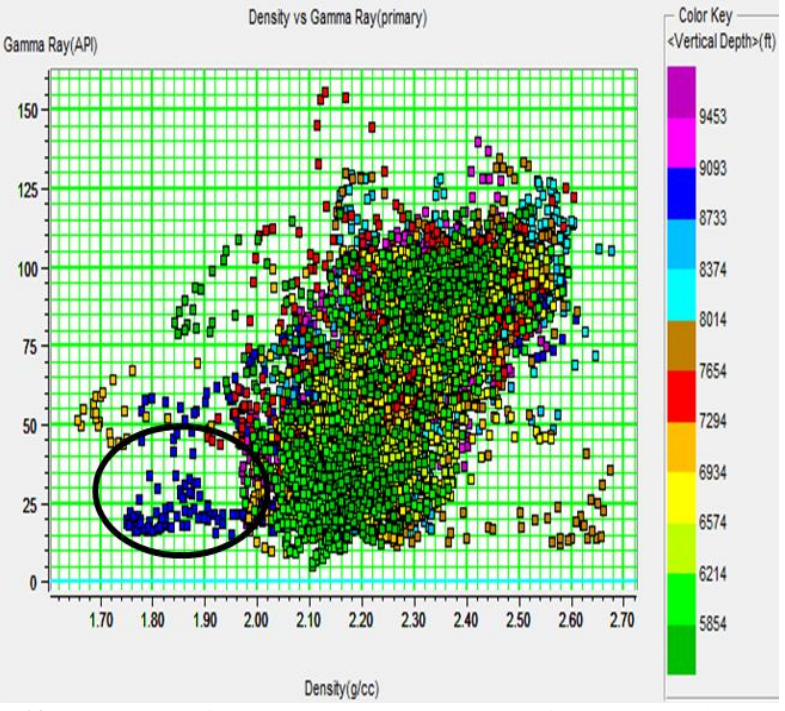

Fig. 10: Cross-Plot of Density against Gamma Ray for Well-A Using Vertical Depth as Color Code with Mapped Reservoir in Black Ellipse.

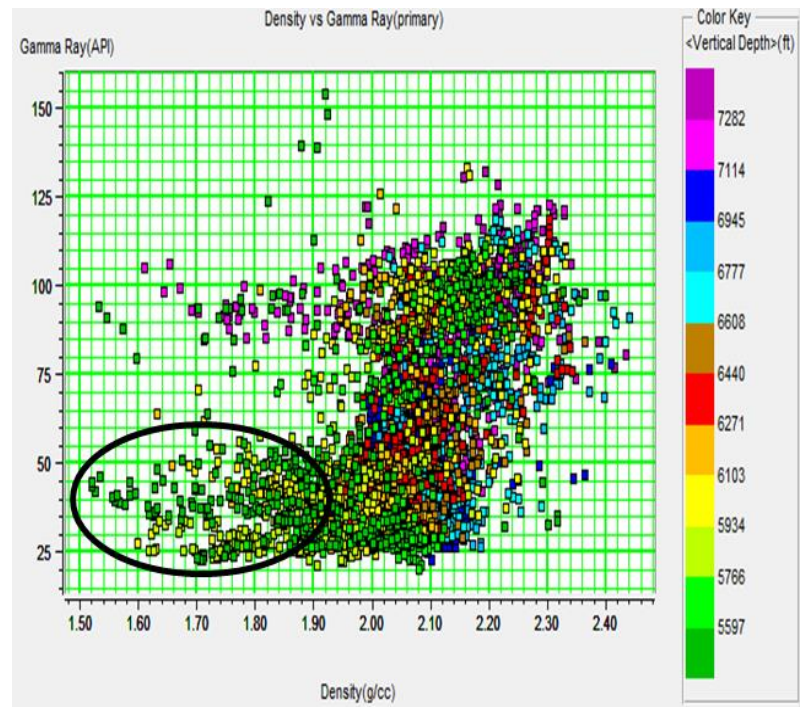

Fig. 11: Cross-Plot of Density Against Gamma Ray for Well-B Using Vertical Depth as Color Code with Mapped Reservoir in Black Ellipse.

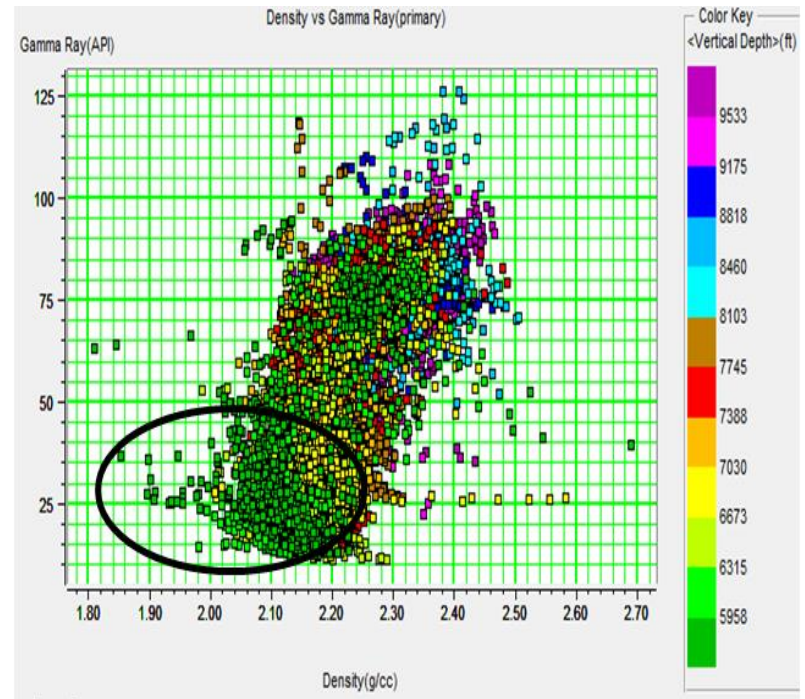

Fig. 12: Cross-Plot of Density Against Gamma Ray for Well-C Using Vertical Depth as Color Code with Mapped Reservoir in Black Ellipse.

Cross-plots as a function of Gamma Ray.

The lowest cluster (blue ellipse) corresponds to the sand zone while the middle cluster (green elipse) corresponds to a unit consisting of an intercalation of sand and shale. The higher cluster of 
high gamma ray and high density values (red ellipse) corresponds to the more shaley interval of the well (fig 13a-15a). The vertical attribute (cross section) of the generated crossplot (fig 13b-15b) shows a clear distinction between sand and shale units with the associated heterolithic interval. In well-A, four reservoir units (A1-A4) were delineated, two reservoir units for well-B (B2-B4) and four reservoir units for well-C (C1-C4) and compiled in Table 2 .

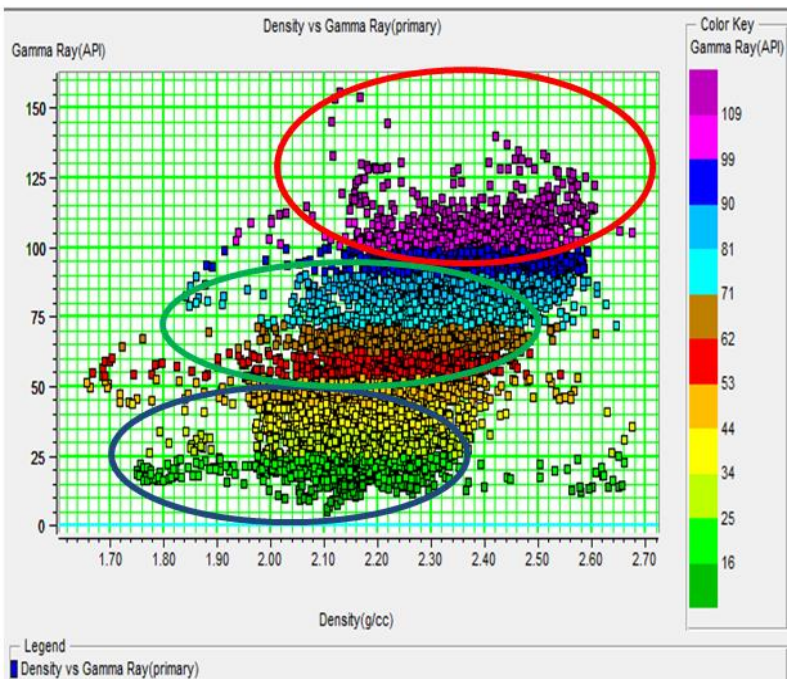

Fig. 13: A) Lithological Identification Cross-Plot of GR-DT for Well-A

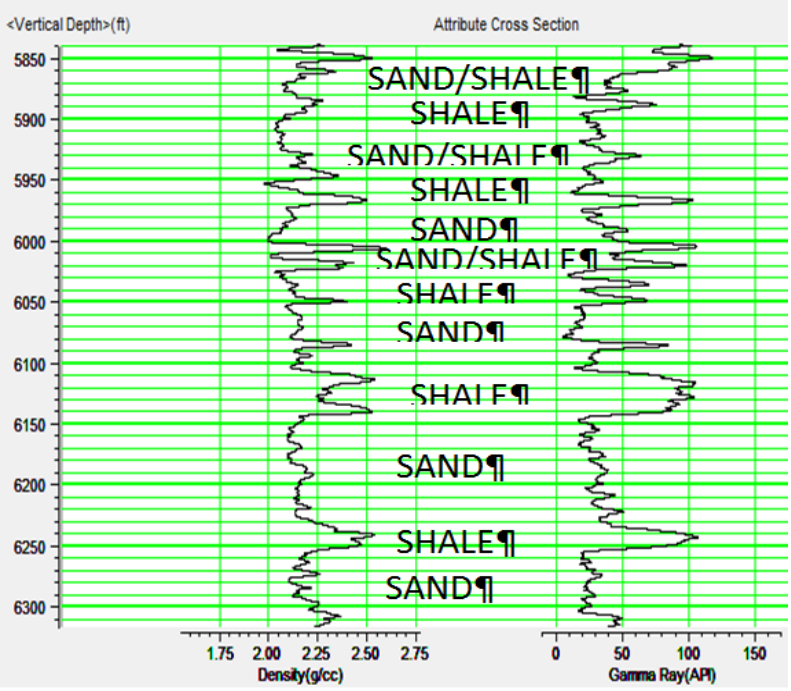

Fig. 13: B) Attribute Cross Section of GR-DT Cross-Plot for Well-A

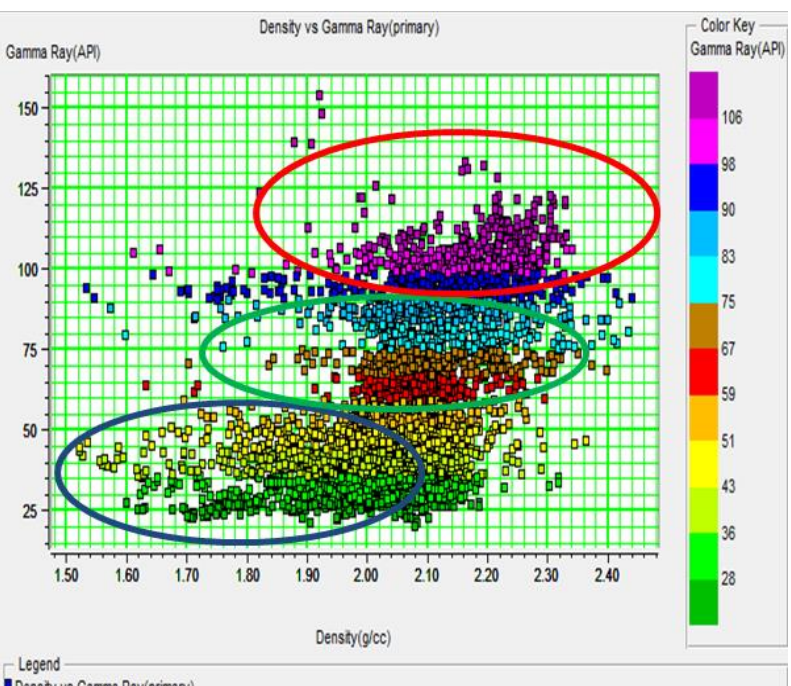

I Densty ys Garma Ray(pimary

Fig. 14: A) Lithological Identification Cross-Plot of GR-DT for Well-B.

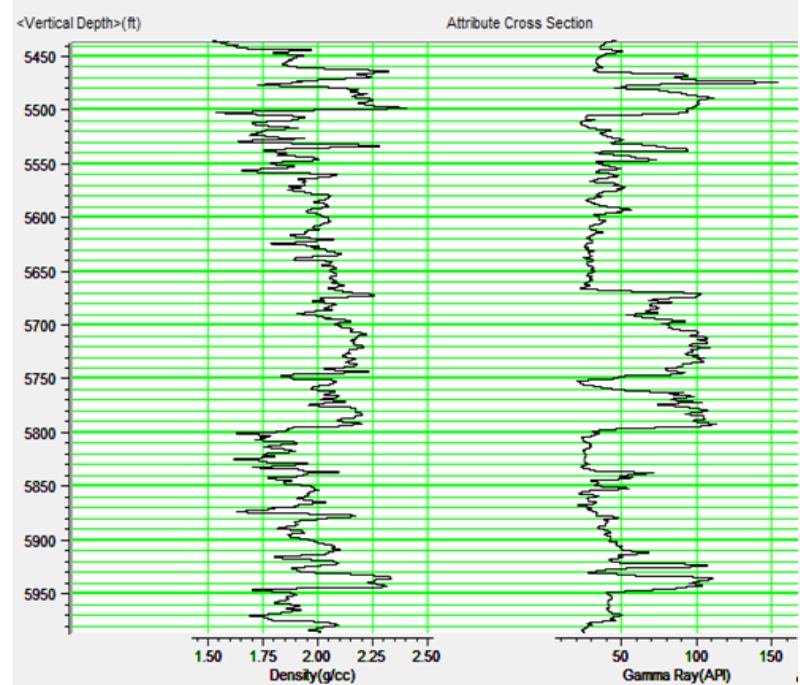

Fig. 14: B) Attribute Cross Section of GR-DT Cross-Plot for Well-B.



Density vs Garma Ray(primary)

Fig. 15: A) Lithological Identification Cross-Plot of GR-DT for Well-C.



Fig 15: B) Attribute Cross Section of GR-DT Cross-Plot for Well-C.

Cross-plots as a function of Porosity

The effective porosity values obtained for the reservoirs range from 26 to $39 \%$, which suggest moderate to good porosity. The average core porosity for the wells (fig 16-18) is in the same range with the calculated porosity (Table 2 ). The average porosity values evaluated for well-A reservoirs range from 29 to $39 \%$, which suggest good porosity values for oil and excellent for gas reservoirs. 


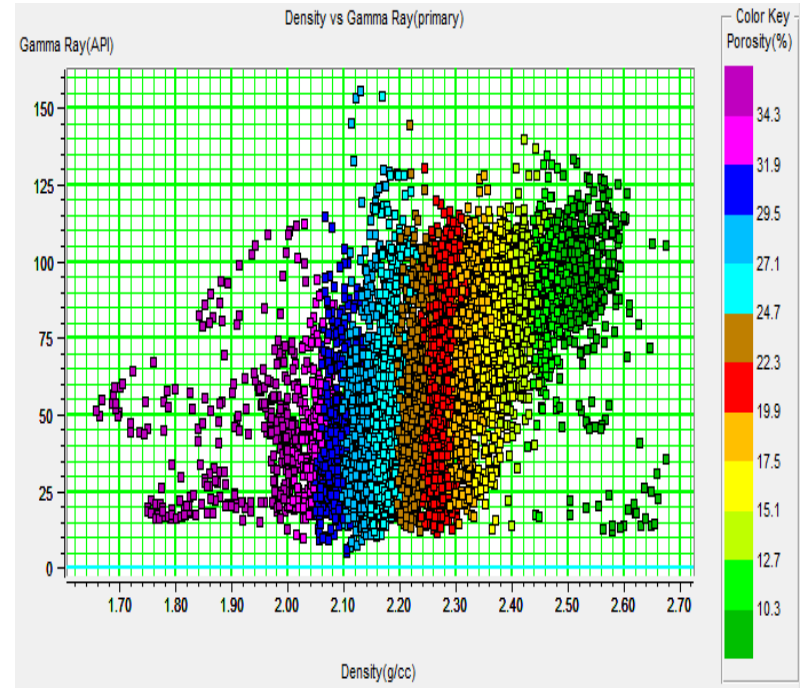

Fig. 16: Cross-Plot of Density against Gamma Ray for Well-A Using Porosity as Color Code.

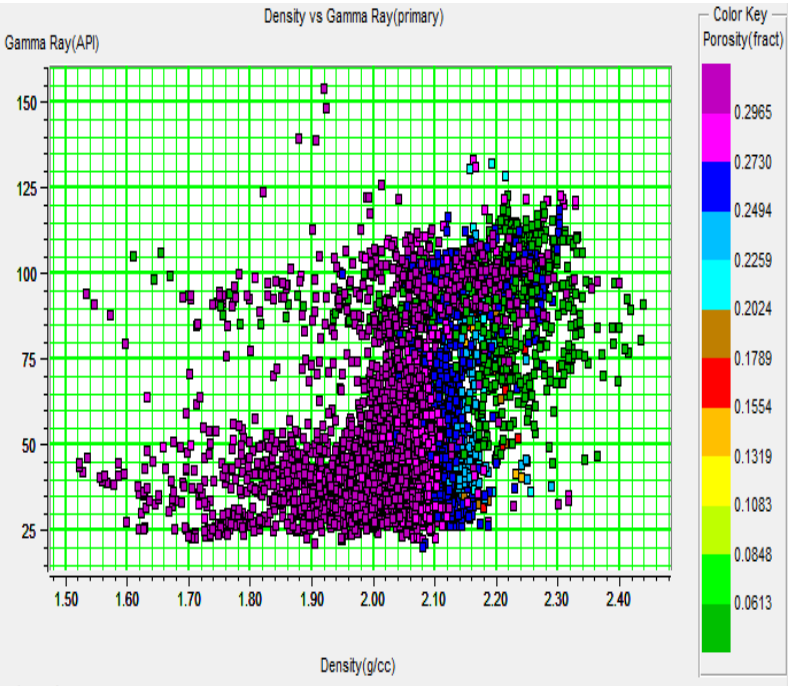

Fig. 17: Cross-Plot of Density against Gamma Ray for Well-B Using Porosity as Color Code.

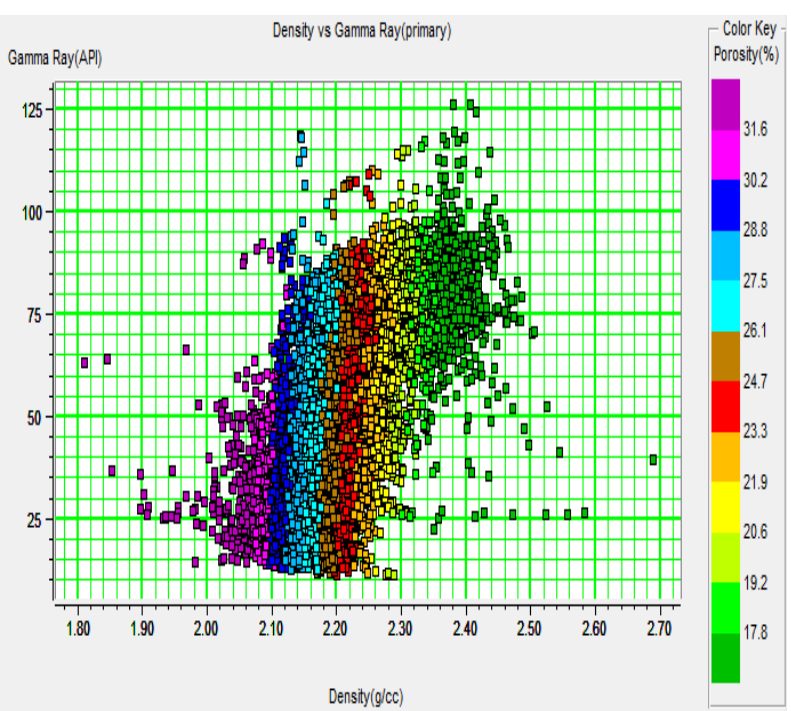

Fig. 18: Cross-Plot of Density against Gamma Ray for Well-C Using Porosity as Color Code.
Cross-plots as a function of Resistivity and water saturation compared

Virtually all reservoirs in the wells are saturated with Hydrocarbon (Fig 19-21) as seen in their very low water saturation values $(\mathrm{Sw}=2-25 \%)$. To validate the low $\mathrm{Sw}$ in the reserviour matched total resistivity values are likewise very high with most of the reservoir between 83 and $100 \Omega \mathrm{m}$. The $\mathrm{C} 1$ and $\mathrm{C} 2$ reservoirs are also evaluated to contain gas with relatively high total resistivity of $12 \Omega \mathrm{m} \mathrm{m}$. This is further confirmed by the low water saturation values of the two reservoirs (Table 2, Fig 21).

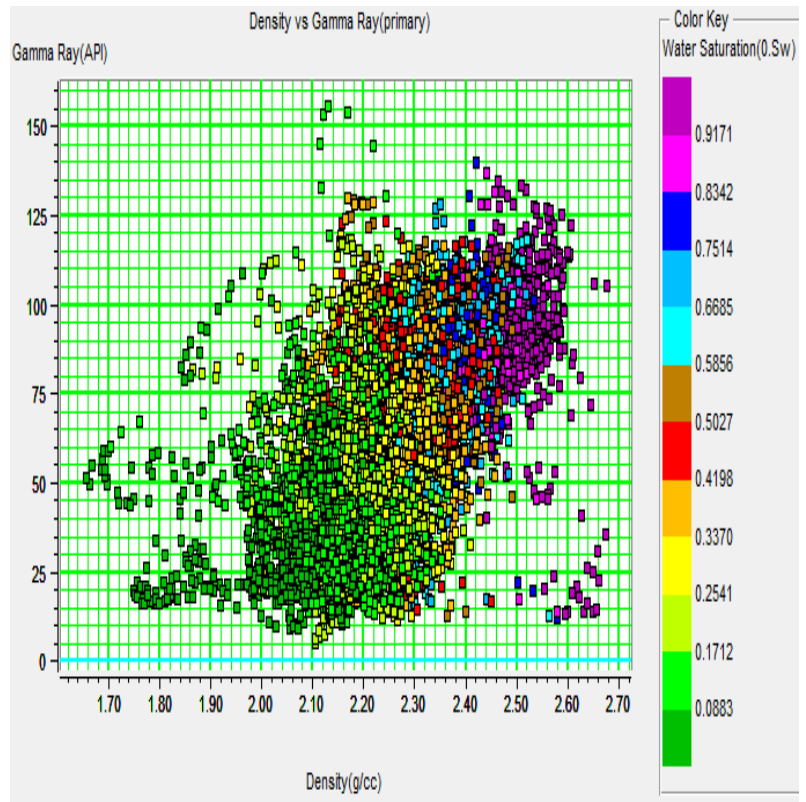

Fig. 19: A) Cross-Plot of Density against Gamma Ray for Well-A Using Water Saturation as Color Code.

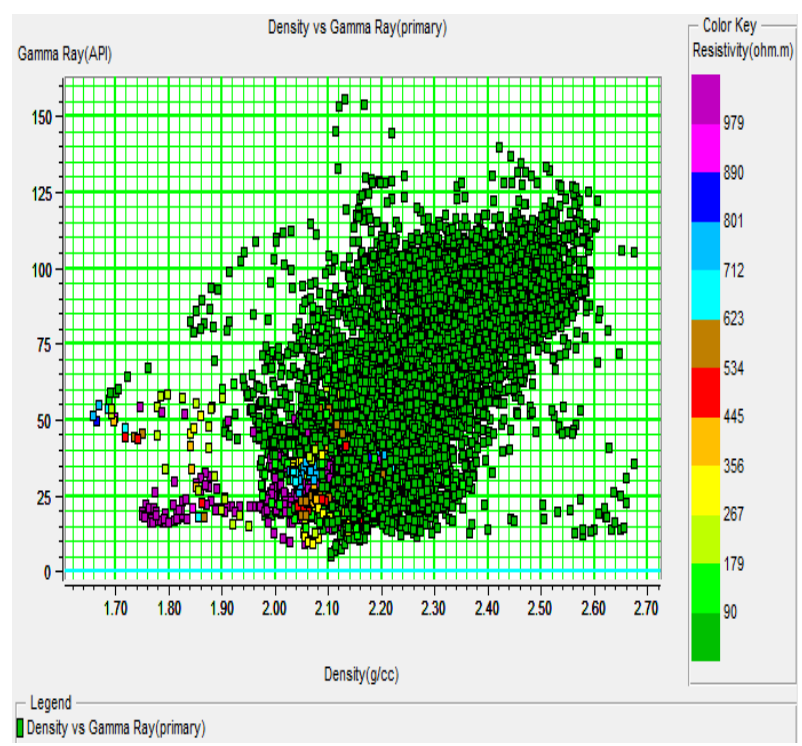

Fig 19: B) Cross-Plot of Density against Gamma Ray for Well-A Using Resistivity as Color Code. 


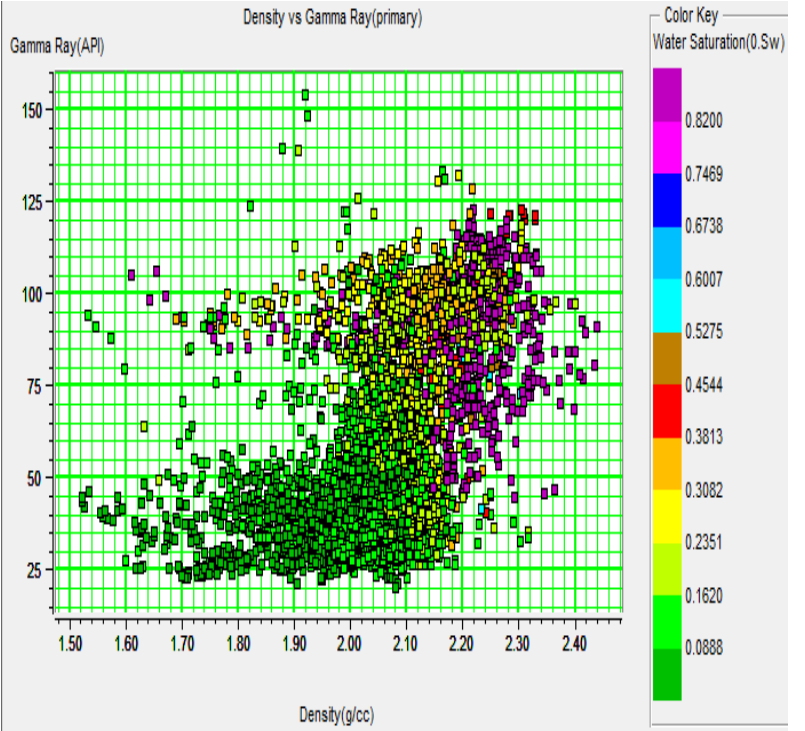

Fig. 20: A) Cross-Plot of Density against Gamma Ray for Well-B Using Water Saturation as Color Code.

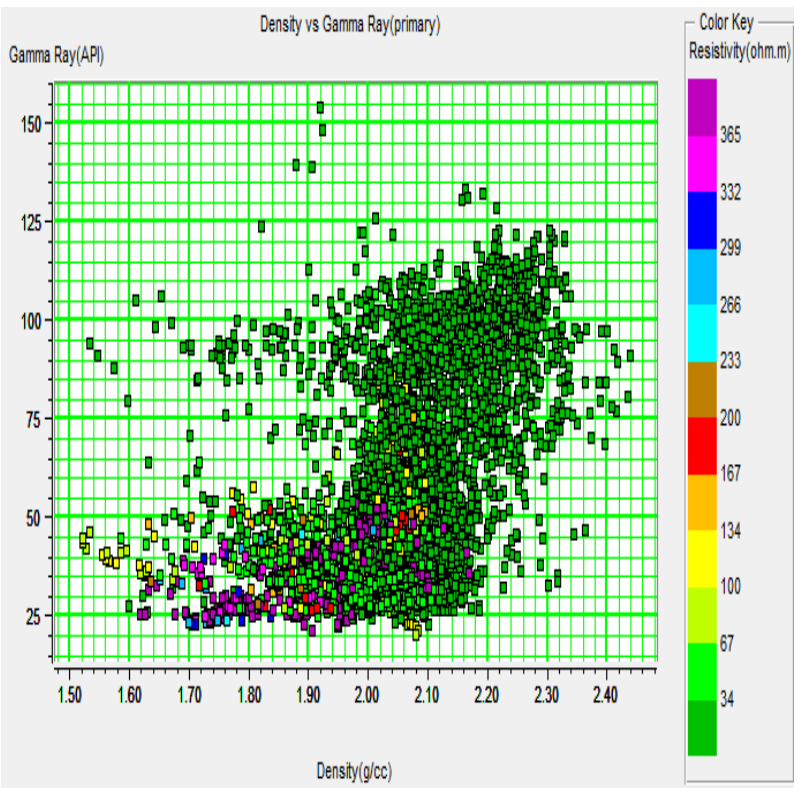

Fig. 20: B) Cross-Plot of Density against Gamma Ray for Well-B Using Resistivity as Color Code.

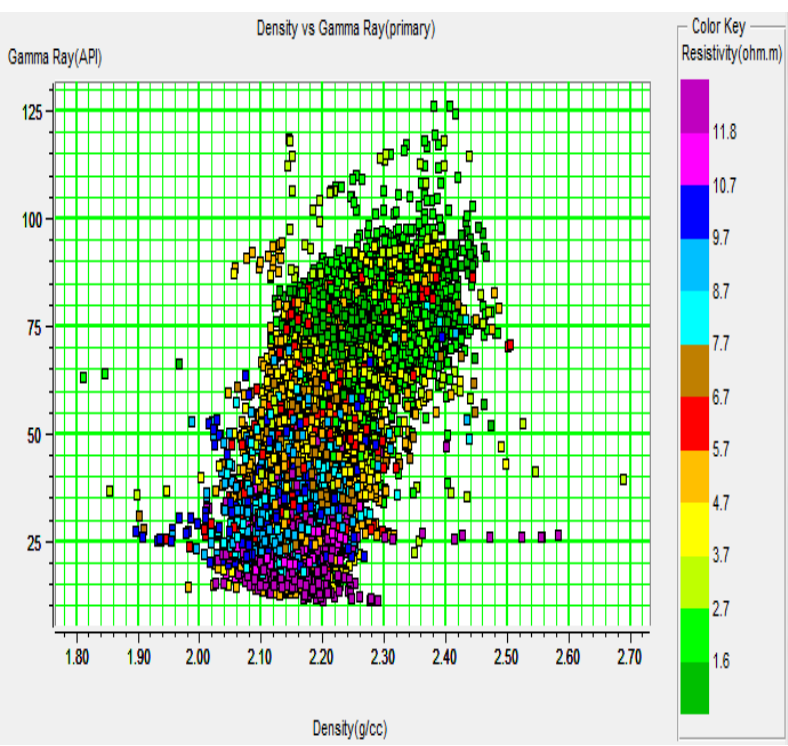

Fig. 21: A) Cross-Plot of Density against Gamma Ray for Well-C Using Water Saturation as Color Code.

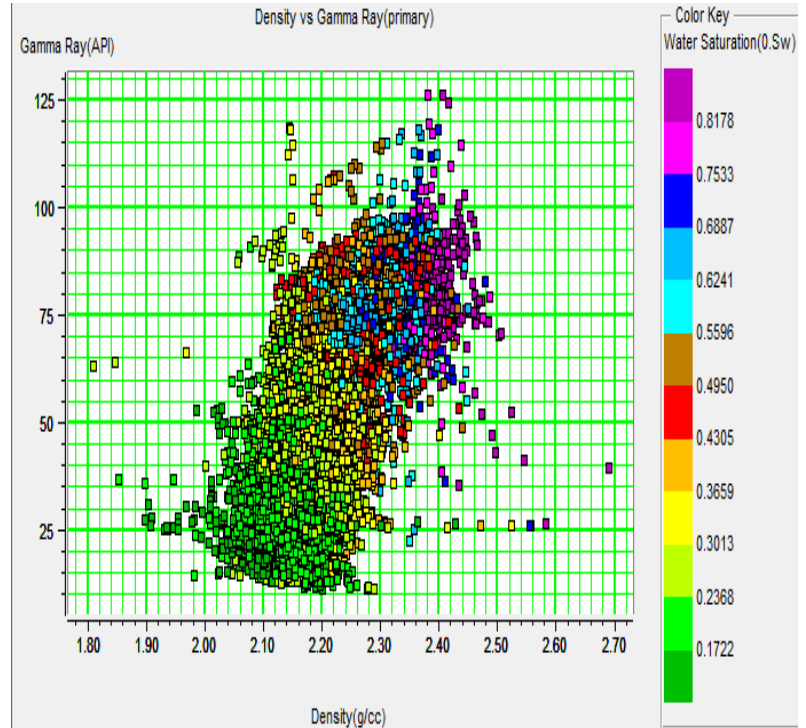

Fig. 21: B) Cross-Plot of Density against Gamma Ray for Well-C Using Resistivity as Color Code.

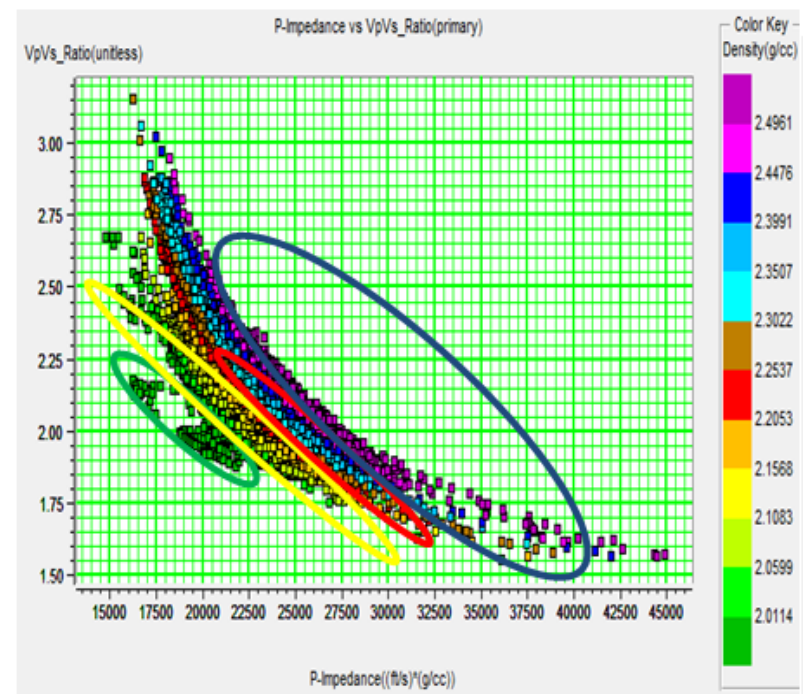

Fig. 22: A) Cross Plot of P-Impedance Verses Vpvs Ratio with Density As Colour Code.

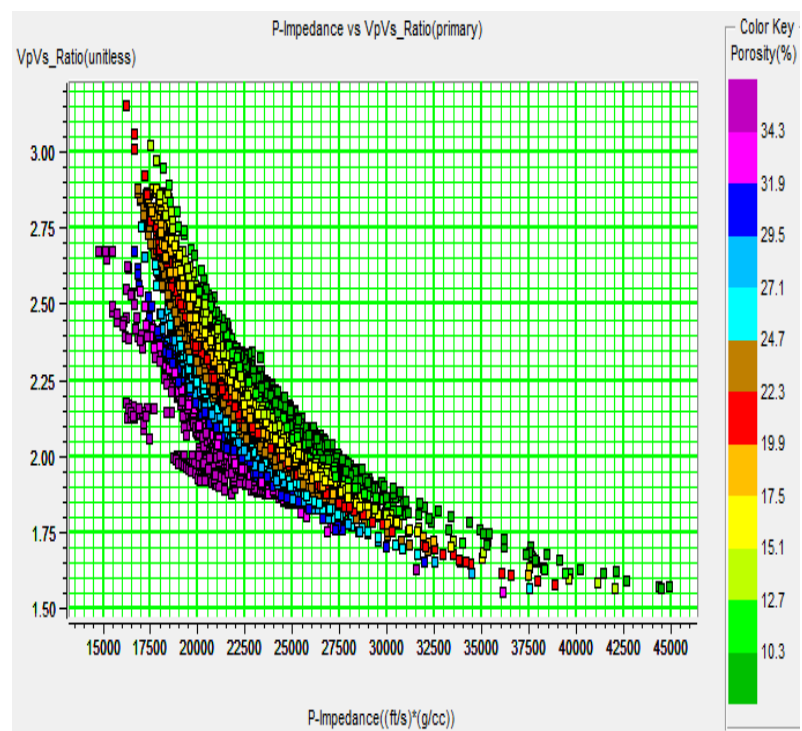

Fig. 22: B) Cross Plot of P-Impedance Verses Vpvs Ratio with Porosity as Colour Code. 




Fig. 23: A) Crossplot Display of Vp/Vs Ratio Versus P-Impedance Showing A Cluster of Points Away from the Wet Background Trend Circled.

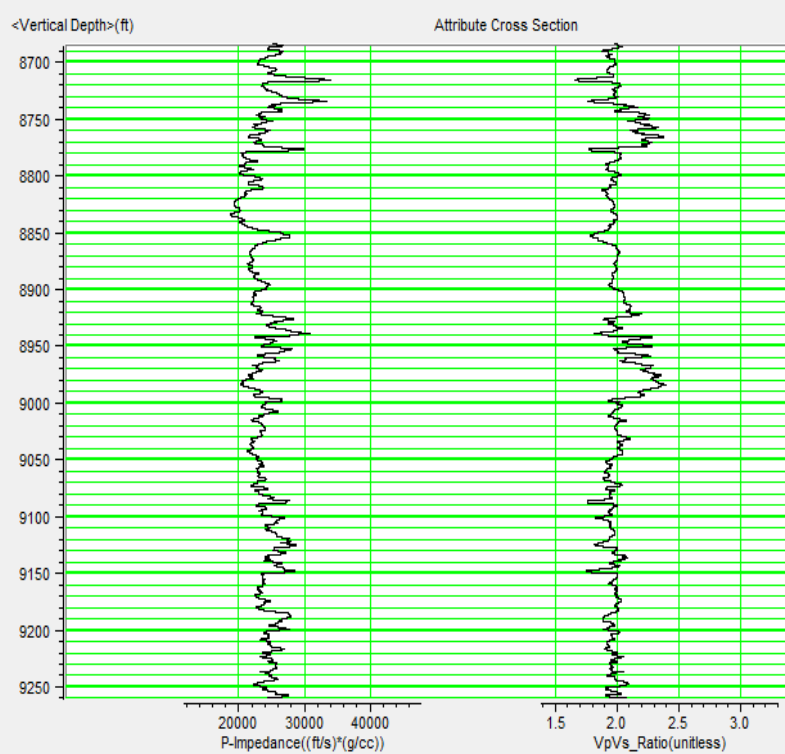

Fig. 23: B) Well Attribute Cross-Section of Vp/Vs Ratio Shows That the Anomalous Data Points Corresponds to A Hydrocarbon Bearing Interval.



Fig. 24: A) Cross Plot Of P-Impedance Verses Vpvs Ratio with Resistivity as Colour Code. Notice the Very High Resistivity in the HC Charged Zone Circled.

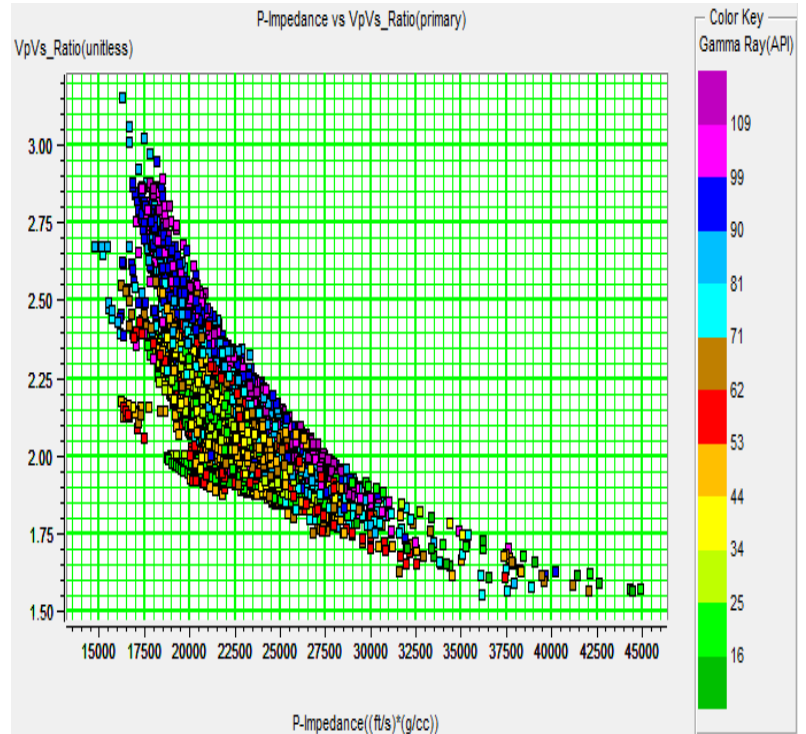

Fig 24: B) Cross Plot of P-Impedance Verses Vpvs Ratio with Gamma Ray as Colour Code. Notice the Low Gamma Ray Values in the HC Charged Zone.

\subsection{Cross-plot of $P$-impedance against VpVs ratio}

The cross plot in fig 22 distinguishes the reservoir into four anomalous zones using density and porosity as colour code which can be interpreted as gas charged zone (green ellipse) having the lowest density and highest porosity, hydrocarbon zone (yellow ellipse), brine zone (red ellipse) and shale zone (blue ellipse). The gas zone is within deeper depth of between $8733 \mathrm{ft}$ to $9000 \mathrm{ft}$ (fig 23 ) and confirms with the gas mapped reservoir in Table 2 . While in figure 24 , two anomalous zones were mapped using resistivity and gamma ray as colour codes, which can be interpreted as hydrocarbon charged zone (yellow ellipse) and brine charged zone (red ellipse). A better discrimination is observed along the Pimpedance which discriminates between fluid and lithology in the reservoir compare to VpVs ratio. This cross-plot shows better fluid as well as lithology discrimination along the acoustic impedance axis, indicating that acoustic impedance attribute will better describe the A-reservoir conditions in terms of lithology and fluid content than $\mathrm{VpVs}$ ratio.

The Sand lithology showed low gamma ray, high resistivity and low acoustic impedance. For the three wells considered, ten reservoirs were observed, four reservoirs was observed in well-A with A4 having a the best sand pay unit containing gas at a depth of $8780 \mathrm{ft}$ to $8900 \mathrm{ft}$. Two oil reservoirs were observed for well-B at a depth of 5500ft to 5910ft. In well-C, four reservoir units were observed (Table 2). The cross-plot of rock properties discriminated the wells into lithologies of sand and shale which is typical of Niger Delta. The crossplot also discriminated the fluids into gas, oil and brine.

\section{Conclusions}

Petrophysical analysis was carried out for all the identified hydrocarbon intervals, from three wells studied. This study has shown that cross-plots of GR-RHOB with various rock attributes like resistivity, water saturation, porosity etc. can be used as an additional tool to delineate lithologies in well logs prior to petrophysical evaluation of the reservoir units. The cross-plots identified mainly sandstone, shale and in some cases intercalations of sand and shale in all the wells. It was observed that the wells within this field were saturated mostly with oil. The results confirmed that the reservoirs have effective porosity values from 26 to $39 \%$, which suggest moderate to good porosity and will allow greater flow of both oil and gas. In the three wells, reservoirs A1, A2, B1, B2, C3 and $\mathrm{C} 4$ were found to contain oil while the rest are gas filled. The study also showed that the gas filled reservoir unit is within deeper 
depth and the cross-plot shows better fluid as well as lithology discrimination along the acoustic impedance axis. This well log analysis method employed is efficient and less expensive in prospecting for hydrocarbons and is reliable when combined with other geophysical methods such as seismic and core analysis.

Table 2: Summary of Petrophysical Results

\begin{tabular}{|c|c|c|c|c|c|c|}
\hline \multicolumn{7}{|l|}{ Well-A } \\
\hline $\begin{array}{l}\text { Reservior } \\
\text { Unit }\end{array}$ & $\begin{array}{l}\text { Interval } \\
\text { (ft) }\end{array}$ & $\begin{array}{l}\text { Net } \\
\text { Sand } \\
\text { (ft) }\end{array}$ & $\begin{array}{l}\text { Avg. } \\
\text { Porosity } \\
(\%)\end{array}$ & $\begin{array}{l}\text { Avg. } \\
\text { water } \\
\text { saturation } \\
(\%)\end{array}$ & $\begin{array}{l}\text { Avg. } \\
\text { resistivity } \\
(\Omega \mathrm{m})\end{array}$ & $\begin{array}{l}\text { Fluid } \\
\text { Suspected }\end{array}$ \\
\hline A1 & $\begin{array}{l}5870- \\
5955\end{array}$ & 85 & 29 & 6 & 83 & Oil \\
\hline $\mathrm{A} 2$ & $\begin{array}{l}6145- \\
6205\end{array}$ & 60 & 28 & 4 & 89 & Oil \\
\hline A3 & $\begin{array}{l}7120- \\
7190\end{array}$ & 70 & 36 & 2 & 89 & Oil/Gas \\
\hline A4 & $\begin{array}{l}8780- \\
8900\end{array}$ & 120 & 39 & 4 & 97 & Gas \\
\hline \multicolumn{7}{|l|}{ Well-B } \\
\hline $\begin{array}{l}\text { Reservior } \\
\text { Unit }\end{array}$ & $\begin{array}{l}\text { Interval } \\
\text { (ft) }\end{array}$ & $\begin{array}{l}\text { Net } \\
\text { Sand } \\
\text { (ft) }\end{array}$ & $\begin{array}{l}\text { Avg. } \\
\text { Porosity } \\
(\%)\end{array}$ & $\begin{array}{l}\text { Avg. } \\
\text { water } \\
\text { saturation } \\
\text { (\&) }\end{array}$ & $\begin{array}{l}\text { Avg. } \\
\text { resistivity } \\
(\Omega \mathrm{m})\end{array}$ & $\begin{array}{l}\text { Fluid } \\
\text { Suspected }\end{array}$ \\
\hline B1 & $\begin{array}{l}5500- \\
5660\end{array}$ & 160 & 32 & 7 & 53 & Oil \\
\hline B2 & $\begin{array}{l}5800- \\
5910\end{array}$ & 110 & 32 & 4 & 90 & Oil \\
\hline \multicolumn{7}{|l|}{ Well-C } \\
\hline $\begin{array}{l}\text { Reservior } \\
\text { Unit }\end{array}$ & $\begin{array}{l}\text { Interval } \\
\text { (ft) }\end{array}$ & $\begin{array}{l}\text { Net } \\
\text { Sand } \\
\text { (ft) }\end{array}$ & $\begin{array}{l}\text { Avg. } \\
\text { Porosity } \\
(\%)\end{array}$ & $\begin{array}{l}\text { Avg. } \\
\text { water } \\
\text { saturation } \\
(\&)\end{array}$ & $\begin{array}{l}\text { Avg. } \\
\text { resistivity } \\
(\Omega \mathrm{m})\end{array}$ & $\begin{array}{l}\text { Fluid } \\
\text { Suspected }\end{array}$ \\
\hline $\mathrm{C} 1$ & $\begin{array}{l}5700- \\
5890\end{array}$ & 190 & 32 & 25 & 12 & Oil/Gas \\
\hline $\mathrm{C} 2$ & $\begin{array}{l}6310- \\
6400\end{array}$ & 90 & 32 & 20 & 12 & Oil/Gas \\
\hline C3 & $\begin{array}{l}6900- \\
7010\end{array}$ & 110 & 26 & 22 & 11 & Oil \\
\hline $\mathrm{C} 4$ & $\begin{array}{l}7120- \\
7230\end{array}$ & 110 & 26 & 22 & 10 & Oil \\
\hline
\end{tabular}

\section{References}

[1] Adewoye O, Amigun J, O and Afuwai C, G. (2015). Lithostratigraphic interpretation and Seismic Attributes Analysis for reservoir characterization in some parts of Niger Delta. Pet Coal 57(1):7684.

[2] Anderson P. F and Gray F. D. (2001) Using LMR for dual attribute lithology identification. Expanded abstracts. SEG, San Antonio.

[3] Anyiam, O. A., Mode, A. W. and Okara, E. S. (2017). The use of cross-plots in lithologydelineation and petrophysical evaluation of some wells in the western Coastal Swamp, Niger Delta. J Petrol Explor Prod Technol. ISSN 2190-0566. Pg 1-11. https://doi.org/1.17/s13202-017-0364-9.

[4] Chatterjee R and Paul S (2012) Application of cross-plotting techniques for delineation of coal and non-coal litho-units from well logs in Jharia Coalfield, India. Geomaterials 2:94-104. https://doi.org/10.4236/gm.2012.24014.

[5] Ekine A S and Ibe A A (2013) Delineation of hydrocarbon bearing reservoirs from surface seismic and well log data (Nembe Creek) in Niger Delta oil field. J Appl Phys 4(3):26-30. https://doi.org/10.9790/4861-0432630.

[6] Gray F and Andersen E C (2000) Case histories: inversion for rock properties. European Association of Geoscientists and Engineers (EAGE). In: 62nd Conference and technical exposition.

[7] Hunze S and Wonik T (2007) Lithological and structural characteristics of the Lake Bosumtwi Impact Crater, Ghana: interpretation of acoustic televierwe images. Meteorit Planet Sci 42(4-5):779-792. https://doi.org/10.1111/j.1945-5100.2007.tb01074.x.

[8] Lamont M G, Thompson T A and Bevilacqua C (2008) Drilling success as a result of probabilistic lithology and fluid prediction: a case study in the Carnarvon Basin, WA. APPEA 48:1-12. https://doi.org/10.1071/AJ07004.

[9] Ohakwere-Eze M C and Adizua O F (2014) Qualitative Delineation of Hydrocarbon bearing Reservoir from Preliminary study of Well
Log Data over an Offshore Niger Delta Field". PacificJournal of Science and Technology. 15(2):293297.

[10] Omudu M L, Ebeniro J O and Olotu S (2007) Optimizing Quantitative Interpretation for Reservoir Characterization: Case Study Onshore Niger Delta: A paper presented at the 31st Annual SPE International Technical Conference and Exhibition in Abuja, Nigeria. 